\title{
Hubungan Beban Kerja Dosen berdasarkan Time and Motion Study dengan Kinerja Dosen Prodi S1 Ilmu Keperawatan Stikes Surabaya
}

\author{
Taufan Citra Darmawan \\ Email : : Tp4n Thefujin@yahoo.com
}

\begin{abstract}
Nursery education needs profesional and qualified graduates. The achievement in the quality of education depends on lecture espicially the labor of lecturer. The achievemen of lecture's in quality, bring about Tridharma of university became the first duty of lecturer, furthermore the purpose of this research is to know the relation between with responsibility towards lecturer's perfomance.

This research use observational analysis method, with cross-sectional as the main framework in this research. This sample use total sampling method. The sample of this research are 7 personel of lecturers which department of S1 Nursery Science STIKES Surabaya, did by observation and questionnaire as the method of collect the data.

Mostly, work responsibility of lecture is on the middle category is $4(57 \%)$ lecturers, the lecture perfomances are categorized as Good and Enough with the same result 3(43\%). The result of this research use bivariant analysis by pearson correlation test are $(p=0,011, r=0,867)$ where the false degree $\alpha \leq 0,05$ which means H1 accepted. It;s meanthere is a relation between work responsibility of lecture with lecturer's perfomance in Departement of S1 Nursery Science STIKES Surabaya.

Lectures with high perfomancecan't leave that student's study. And lecturer with low perfomance must be fixed their self.
\end{abstract}

Keyword: The Healing II Degree Burns, Honey, Virgin Coconut Oil

\begin{abstract}
ABSTRAK
Pendidikan keperawatan memerlukan lulusan yang professional dan berkualitas, pencapaian kualitas pendidikan ditentukan oleh tenaga pengajar terutama dosen. Pencapaian kualitas dosen dalam melaksanaan Tridharma Perguruan Tinggi menjadi tugas utama dosen yang disebut beban kerja dosen, adapun tujuan penelitian ini adalah untuk menganalisis kinerja dosen yang dihubungkan dengan beban kerja yang dimiliki oleh dosen

Penelitian ini menggunakan metode observasional analitik, dengan rancang penelitian crosssectional. Penelitian ini menggunakan metode total sampling. Sampel penelitian ini sebanyak 7 personel dosen yang dilakukan di Prodi S1 Ilmu Keperawatan STIKES Surabaya, dengan pengumpulan data observasi dan kuisioner.

Hasil penelitian menunjukan Sebagian besar beban kerja dosen berada pada kategori Sedang sebanyak 4 (57\%) dosen, kinerja dosen didapati kategori Baik dan Cukup dengan nilai yang sama sebanyak 3 (43\%). Hasil penelitian menggunakan analisis bivariant dengan uji korelasi pearson didapatkan hasil $(\mathrm{p}=0.011, \mathrm{r}=0,867)$ dimana tingkat kesalahan $\alpha \leq 0,05$ yang berarti H1 diterima, berarti ada hubungan antara beban kerja dosen dengan kinerja dosen di Prodi S1 Ilmu Keperawatan STIKES Surabaya.

Dosen dengan beban kerja yang tinggi diharapkan tidak mengabaikan tugas mengajar kepada mahasiswa dan dosen kinerja rendah diharapkan segera berbenah diri.
\end{abstract}

Kata Kunci:Beban Kerja Dosen, Kinerja, Time And Motion Study 


\section{PENDAHULUAN}

Kinerja oleh dosen selama ini memiliki peranan penting dalam proses pendidikan, penelitian dan pengabdian pada masyarakat, banyaknya tuntutan akan kinerja yang prosesional sesuai dengan tugas dan jabatannya dosen menentukan kualitas pelaksanaan Tridharma Perguruan Tinggi. Pada kenyataanya masih banyak tenaga pengajar (dosen) belum memenuhi tugas untuk melaksanakan fungsi, peran, dan kedudukan sesuai tugas dan jabatan. Untuk mencapai hasil tersebut diperlukan kinerja yang dapat diandalkan. (Dirjen Dikti, 2010. DalamHeryati, 2013).

Dari hasil wawancara kepada beberapa Mahasiswa Prodi S1 Ilmu Keperawatan yang di lakukan pada 28 Nopember 2016 dari 12 mahasiswa acak dari semesterenam, didapatkan hasilpoin pertama, "apakah dosen sering menunda tatap muka perkuliahan ?" sebanyak $12 \quad(100 \%)$ mahasiswa setuju bahwa dosen sering menunda perkuliahan, poin dua "apakah dosen sering datang terlambat ?" sebanyak 7 (58\%) mahasiswa sependapat, dan poin ketiga "apakah dosen tidak mengisi perkuliahan sesuai SKS atau pulang lebih awal ?" sebanyak 10 (83\%) mahasiswa setuju dan menambahkan pendapat dengan berbagai alasan seperti pelatihan, kuliah, akreditasi, dan aktivitas lain diluar, begitu pula di bidang penelitian,wawancara di bidang pengabdian masyarakat juga di dapatkan keluhan poin terakhir yaitu poin empat "apakah saat mahasiswa mengadakan penyuluhan tentang promosi kesehatan di masyarakat, beberapa dari dosen pembimbing tidak dapat menghadiri bahkan diwakilkan oleh dosen lain dengan berbagai alasan ?" sebanyak 5 (41\%) mahasiswa sependapat dan juga menambahkan bahwa ada juga beberapa dosen sangat yang membantu saat acara pengabdian masyarakat. Beban kerja yang berbeda dari tiap dosen menyebabkan perbedaan pada kinerja dosen, terutama saat mendampingi mahasiswa saat pengabdian kepada masyarakat dan juga penelitian bersama mahasiswa.

Berdasarkan kegiatan professional dosen, capaian kualitas tridarma dosen ditunjukkan melalui kinerja dosen (Dirjen Dikti, 2010). Kinerja yang dihasilkan dosen tidak lepas dari faktor yang mempengaruhi. Penilaian pencapaian kinerja memerlukan pengkajian terkait faktor yang mempengaruhi belum maksimalnya kinerja dosen salah satunya adalah beban kerja, (Suwarni. 2008). Pelaksanaan tridarma pergruruan tinggi adalah tugas utama dosen yang normalnya dilakukan sebanyak 12 sks meliputi penelitian, pengabdian, dan pembelajaran. (Murdiyani, 2010). Ada beberapa tehnik pendekatan yang dapat digunakan untuk mengukur beban kerja dosen diantaranya work sampling, daily log dan Time and Motion Study. Pengukuran beban kerja dilakukan oleh peneliti dengan model time and motion study demi memperoleh gambaran aktifitas dosen, kelebihan dari tehnik ini adalah peneliti mampumenilai kualitas kinerja dari sampel sambil menghitung beban kinerja, (Ilyas, 2011).

Berdasarkan latar belakang diatas, dapat diketahui bahwa menurunya kinerja dapat disebabkan oleh beberapa faktor salah satunya beban kerja.Peneliti mencoba membuktikan adanya hubungan antara beban kerja berdasarkan penggunaan metode Time and Motion Studyguna mengetahui efektifitas dari kinerja dosen di Prodi S1 Ilmu Keperawatan STIKES Surabaya. Tujuan penelitian ini adalah Mengetahui hubungan beban kerja berdasarkan Time and Motion Studydengan kinerja Dosen Prodi S1 Ilmu Keperawatan STIKES Surabaya.

\section{BAHAN DAN METODE}

Pada penelitian ini peneliti menggunakan metode penelitian observasional analitik yaitu suatu penelitian yang dilakukan tanpa melakukan intervensi terhadap subjek penelitian (Notoatmodjo, 2012). Pada penelitian ini, peneliti ingin mengetahui hubungan beban kerja berdasarkan Time and Motion Study dengan kinerja dosen Prodi S1 Ilmu Keperawatan STIKES Surabaya.

Populasi dalam penelitian ini adalah dosen Prodi S1 Ilmu Keperawatan berjumlah 7 orang. Teknik sampling dalam penelitian ini menggunakan metode total sampling yang melibatkan semua tenaga dosen pengajar sejumlah 7 orang.

Tehnik pengumpulan data dalam penelitian ini ada 2, pada beban kerja menggunakan tehnik pendekatan Time and MotionStudy yang merupakan salah satu jenis dari studi observasi, dimana peneliti mengamati dan mengikuti kegiatan yang 
dilakukan personel, tehnik ini efektif untuk mendapatkan kualitas kinerja dari beban kerja tiap personel (Nursalam, 2015). Sedangkan pada kinerja dosen menggunakan penilaian kuesioner dari mahasiswa.Kuesioner merupakan teknik pengumpulan data yang dilakukan dengan cara memberi seperangkat pertanyaan atau pernyataan tertulis kepada responden. Sedangkan untuk hasil penelitian, di analisis dan diolah dengan menggunakan uji Pearson Correlation untuk mendapatkan hasil dari hubungan beban kerja dengan kinerja dosen.

\section{HASIL}

Bagian pertama akan diuraikan tentang data umum karakteristik 7 orang personel berdasarkan kategori pendidikan, usia, jenis kelamin, lama bekerja dan penghasilan.

Tabel 1 Distribusi frekuensi dosen berdasarkan usia di Prodi S1 Ilmu Keperawatan STIKES Surabaya tanggal 5 juni 2017

\begin{tabular}{llll}
\hline No & Usia & $\begin{array}{l}\text { Jumlah } \\
(\mathrm{N})\end{array}$ & Presentase (\%) \\
\hline 1 & $\begin{array}{l}21-25 \\
\text { tahun }\end{array}$ & 2 & $29 \%$ \\
\hline 2 & $\begin{array}{l}26-30 \\
\text { tahun }\end{array}$ & 5 & $71 \%$ \\
\hline \multicolumn{2}{l}{ Total } & 7 & $100 \%$ \\
\hline
\end{tabular}

Tabel 2 Distribusi frekuensi dosen berdasarkan jenis kelamin di Prodi S1 Ilmu Keperawatan STIKES Surabaya tanggal 5 juni 2017.

\begin{tabular}{llll}
\hline No & $\begin{array}{c}\text { Jenis } \\
\text { kelamin }\end{array}$ & $\begin{array}{c}\text { Jumlah } \\
(\mathrm{N})\end{array}$ & $\begin{array}{c}\text { Presentase } \\
(\%)\end{array}$ \\
\hline 1 & Laki-laki & 5 & $71 \%$ \\
\hline 2 & Perempuan & 2 & $29 \%$ \\
\hline Total & 7 & $100 \%$ \\
\hline
\end{tabular}

Tabel 3 Distribusi frekuensi dosen berdasarkan lama bekerja di Prodi S1 Ilmu Keperawatan STIKES Surabaya tanggal 5 juni 2017.

\begin{tabular}{llll}
\hline No & $\begin{array}{l}\text { Lama } \\
\text { bekerja }\end{array}$ & $\begin{array}{l}\text { Jumlah } \\
(\mathrm{N})\end{array}$ & $\begin{array}{l}\text { Presentase } \\
(\%)\end{array}$ \\
\hline 1 & $\begin{array}{l}0-2 \\
\text { tahun }\end{array}$ & 3 & $43 \%$ \\
\hline 2 & $\begin{array}{l}2-4 \\
\text { tahun }\end{array}$ & 4 & $57 \%$ \\
\hline
\end{tabular}

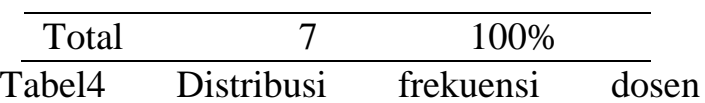
berdasarkan penghasilan di Prodi S1 Ilmu Keperawatan STIKES Surabaya tanggal 5 juni 2017.

\begin{tabular}{cccc}
\hline No & penghasilan & $\begin{array}{c}\text { Jumlah } \\
(\mathrm{N})\end{array}$ & $\begin{array}{c}\text { Presentase } \\
(\%)\end{array}$ \\
\hline 1 & $1-3$ juta & 5 & $71 \%$ \\
\hline 2 & $3-5$ juta & 2 & $29 \%$ \\
\hline Total & & 7 & $100 \%$ \\
\hline
\end{tabular}

Tabel 5 Distribusi frekuensi dosen berdasarkan pendidikan di Prodi S1 Ilmu Keperawatan STIKES Surabaya tanggal 5 juni 2017.

\begin{tabular}{cccc}
\hline No & Pendidikan & $\begin{array}{l}\text { Jumlah } \\
(\mathrm{N})\end{array}$ & $\begin{array}{l}\text { Presentase } \\
(\%)\end{array}$ \\
\hline 1 & S1 & 3 & $43 \%$ \\
\hline 2 & S2 & 4 & $57 \%$ \\
\hline & Total & 7 & $100 \%$
\end{tabular}

Pada bagian ini akan diuraikan data khusus tentang hubungan dari setiap variable yang ada

Tabel 6 Distribusi frekuensi beban kerja dosen berdasarkan time and motion study tanggal 1 juni 2017.

\begin{tabular}{llll}
\hline No & $\begin{array}{l}\text { Beban } \\
\text { Kerja } \\
\text { Dosen }\end{array}$ & N & $\begin{array}{l}\text { Presentase } \\
(\boldsymbol{\%})\end{array}$ \\
\hline 1. & Overload & 2 & $29 \%$ \\
\hline 2. & Sedang & 4 & $57 \%$ \\
\hline 3. & Underload & 1 & $14 \%$ \\
\hline Jumlah & $\mathbf{7}$ & $\mathbf{1 0 0 \%}$ \\
\hline
\end{tabular}

Tabel 7 Distribusi frekuensi kinerja dosen di Prodi S1 Ilmu Keperawatan STIKES Surabayatanggal 10 mei 2017.

\begin{tabular}{cccc}
\hline No & Kinerja & N & Presentase (\%) \\
\hline 1. & Baik & 3 & $43 \%$ \\
\hline 2. & Sedang & 3 & $43 \%$ \\
\hline 3. & Kurang & 1 & $14 \%$ \\
\hline Jumlah & $\mathbf{7}$ & $\mathbf{1 0 0 \%}$ \\
\hline
\end{tabular}

Tabulasi silang hubungan beban kerja berdasarkan time and motion studydengan kinerja dosen didapatkan hasil Beban kerja Overload dengan Kinerja Baiksebanyak 2 (29\%) personel danBeban kerja Sedang dengan Kinerja Baik sebanyak 1 (14\%) personel. Beban kerja Sedang dnegan Kinerja 
Cukup sebanyak 3 (43\%) personel. Beban kerja Underload dengan Kinerja Kurang sebanyak $1(14 \%)$ personel dosen dengan nilai $\mathrm{r}=0,867$.

Berdasarkan hasil analisa dengan bantuan komputerisasi program SPSS uji korelasi Pearson didapatkan nilai korelasi $\mathrm{p}=$ 0,011 , nilai $\mathrm{p}<(0,05)$, sehingga $\mathrm{H} 0$ ditolak dan $\mathrm{H} 1$ diterima yang artinya terdapat hubungan antara beban kerja dengan kinerja dosen di Prodi S1 Ilmu Keperawatan STIKES Surabaya.

\section{PEMBAHASAN}

Hubungan beban kerja berdasarkan Time and Motion Study dengan kinerja dosen Prodi S1 Ilmu Keperawatan STIKES Surabaya.

Berdasarkan hasil uji korelasi pearson menggunakan SPSS versi 16, diperoleh hasil $\mathrm{p}$ value 0,011 level of significant $\alpha=0,05$ berarti terdapat hubungan antara beban kerja dengan kinerja dosen. Hasil menunjukan bahwa H0 ditolak dan $\mathrm{H} 1$ diterima yang berarti ada hubungan antara variabel beban kerja dengan variabel kinerja dosen. Menurut peneliti ada faktor karakteristik yang mempengaruhi hasil kinerja dosen sesuai dengan teori kopelman yaitu dosen penghasilan dan pendidikan.

Tridharma perguruan tinggi dapat dipenuhi oleh dosen dengan melaksanakan beban kerja sepadan dengan 12-16 sks setiap semester. Pemangku kepentingan perlu medapatkan informasi terkait pelaporan pelaksanaan dan evaluasi kinerja yang telah dilakukan oleh doesn. Proses ini nantinya berdampak pada tunjangan dosen dan profesi pendidik. Apabila tidak sesuai seorang pemimpin perguruan tinggi berkewajiban melakukan teguran lisan, peringatan tertulis, penghentian sementara ataupun permanen (Puslatdikkes, 2014).

Kinerja merupakan gambaran pencapaian achievement suatu program kegiatan perencanaan strategis dan operasional organisasi (efforts) oleh seseorang/sekelompok orang di dalam suatu organisasi secara kuantitas dan kualitas, sesuai dengan kewenangan dan tugas tanggung jawabnya, legal dan tidak melanggar hukum, etika dan moral.Kinerja sendiri merupakan penjabaran visi, misi, tujuan dan strategi organisasi. Kinerja sebagai fungsi interaksi antara kemampuan
( $\mathrm{A}=$ ability), motivasi (M=motivation) dan kesempatan $\quad(\mathrm{O}=$ opportunity $) \quad$ Dalam perkembangannya disadari bahwa dalam melaksanakan fungsi dan kegiatan karyawan berhubungan dengan kepuasan dan tingkat besaran imbalan (Nursalam, 2013).

Beban kerja yang tinggi dapat disebabkan oleh beberapa faktor diantaranya kemampuan kerja seseorang. Kemampuan kerja tersebut berkaitan erat dengan tingkat pendidikan yan ditempuh, pengalaman, lama bekerja, dan juga penghargaan dari organisasi tentunya berpengaruh baik secara langsung maupun tidak. (Endang. 2016).

Dosen yang mempunyai pangkat dan golongan, masa kerja, dan tingkat pendidikan yang lebih tinggi seharusnya memperlihatkan kinerja yang lebih baik. Dosen yang memiliki beban kerja tinggi dapat mempengaruhi kinerja dalam berbagai bentuk seperti jam mengajar, kesibukan dan lain-lain. Tingginya beban kerja akan menimbulkan dampak fisiologis maupun psikologis, hal ini sesuai dengan data yang didapatkan saat pengambilan data awal, beberapa dari mahasiswa mengeluh bahwa beberapa personel dosen dengan aktivitas yang sibuk cenderung labil dalam emosional. Sedangkan pada beban kerja yang rendah, menurut peneliti penyebabnya ada 2 yang pertama adalah penghargaan menurut teori kopelman, disini peneliti mengambilpoin penghasilan yang didapatkan sebagai bentuk penghargaan bekerja dalam organisasi, dimana semakin tinggi penghasilan maka kepuasan personel akan meningkat dan kinerja pun juga semakin baik karena faktor ini yang menurut peneliti lebih berpengaruh daripada tingkat pendidikan.Yang kedua yaitu pekerjaan yang dilakukan berulang, pengulangan kegiatan akan menimbulkan kebosanan. Kebosanan dalam kegiatan mengajar dosen yang berulang sedikit banyak dapat mengakibatkan kurangnya perhatian pada pekerjaan sehingga secara potensial menyebabkan rendahnya nilai evaluasi dalam penelitian. Akan tetapi juga tidak tertutup kemungkinan ada faktor lain diluar lingkup penelitian ini yang masih perlu dikembangkan atau diteliti lebih lanjut oleh peneliti selanjutnya. 


\section{SIMPULAN}

Menurut peneliti hasil dari Adanya hubungan, dipengaruhi oleh penghasilan, karena penghasilan adalah bentuk dari penghargaan dalam bekerja, hal ini sesuai dengan teori kopelman dimana penghargaan salah satu faktor yang mempengaruhi kinerja individu. Hasil uji korelasi pearson didapatkan hasil significant 0.011 dimana tingkat kesalahan kurang dari nilai $\alpha 0,05$ yang berarti ada hubungan antara beban kerja dosen dengan kinerja dosen di Prodi S1 Ilmu Keperawatan STIKES Surabaya.

\section{SARAN}

Perlu dilakukan penelitian lebih lanjut menggunakan time and motion study, karena menurut peneliti jenis penelitian kualitatif mungkin akan lebih cocok diterapkan pada tehnik pengamatan dengan menggunakan alat ukur ini.

\section{DAFTAR PUSTAKA}

Andini S. 2013. 'Analisa Kebutuhan Tenaga Keperawatan di Instalasi Hemodialisa Rumah Sakit Umum Pusat Persahabatan Berdasarkan Beban dan KompetensiKerja', Fakultas Kesehatan Masyarakat. Universitas Indonesia. Depok.

Anugrah S. 2011. 'Analisa Kebutuhan Tenaga Dengan Metode Work Load Indicator Staffing Need (WISN)Di Unit Pelatihan Dan Pengembangan Rumah Sakit Tebet', Fakultas Kesehatan Masyarakat Universitas Indonesia. Jakarta.

Arikunto, S. 2010. Prosedur Penelitian: Suatu Pendekatan Praktik. Edisi Revisi. Jakarta: Rineka

Azwar, S. 2012. Reliabilitas dan Validitas. Edisi 4, Yogyakarta: Pustaka Pelajar

Dirjen Dikti Depdiknas, 2014. Pedoman Beban Kerja Dosen dan Evaluasi Pelaksanaan Tri Dharma Perguruan Tinggi. Jakarta: Dirjen Dikti.

Trihastuti E. 2016. 'Pengaruh Kepemimpinan,Motivasi Dan Beban Kerja Terhadap Kinerja Perawat Dalam Pendokumentasian Asuhan Keperawatan Di Ruang Rawat Inap Penyakit Dalam Rumah Sakit X', Prodi Pendidikan Ners Fakultas Keperawatan Universitas Airlangga. Surabaya.
Heriati, T. 2013. 'Faktor-faktor Mendasar yang Mempengaruhi Kineija Dosen Perguruan Tinggi Swasta Dalam Menghasilkan Prestasi Hasil belajar Mahasiswa', Prodi Administrasi Pendidikan, Universitas Pendidikan Indonesia.Depok.

Ilyas, Yaslis. 2011. Perencanaan SDM Rumah Sakit, Teori. Metoda dan Formula. Pusat Kajian Ilmu Kesehatan FKM-UI. Depok : CV Usaha Prima.

LPM STIKES Surabaya. 2015. Pedoman Evaluasi Dosen Oleh Mahasiswahttp://nersstikesby.blogspot.co.id.Diakses pada tanggal 11 Desember 2016.

Lutfi A. 2011.'Pengaruh Setres dan Kepuasan Kerja Terhadap Kinerja Perawat', Fakultas Ekonomi Universitas Diponogoro. Semarang.

Murdiyani, H. 2010. 'Pengaruh Beban Kerja, Kepuasan Kerja Dan Komitmen Organisasi Terhadap Kinerja Dosen Tetap', Fakultas Ilmu Kesehatan Universitas Muhammadiyah Surabaya. Surabaya.

Notoatmodjo, S. 2012. Metodologi Penelitian Kesehatan. Edisi Revisi. Jakarta : Rineka Cipta

Nursalam, 2015. Metodologi Penelitian Ilmu Keperawatan. Edisi 4 Jakarta : Salemba Medika

Nursalam, 2015. Manajemen Keperawatan : Aplikasi dalam Praktik Keperawatan Profesional. Edisi 5 Jakarta : Salemba Medika

Oktaviani, I. \& Weliyati, 2015. 'FaktorFaktor yang Berhubungan dengan Kinerja Dosen di Jurusan Kebidanan Poltekkes Tanjungkarang', Prodi Kebidanan Metro Poltekkes Tanjungkarang. Lampung.

Sugiyono, 2010. Statistika Untuk Penelitian. Bandung : Alfabeta

Sugiyono, 2012. Metode Penelitian Kualitatif Kuantitatif dan $R \& D$. Bandung : Alfabeta

Hidayat S. 2014.'Hubungan Mutu Pelayanan Keperawatan Dengan Kepuasan Pasien Di Ruang Rawat Inap Puskesmas Batulengger Kecamatan Sokobanah Sampang Madura', Stikes Surabaya. Surabaya.

Suwarni, A. 2008. 'Pengaruh Kecerdasan Emosional, Kompetensi, dan Motivasi Terhadap Kinerja Dosen di Program Studi Ilmu Keperawatan Universitas Sahid 
Surakarta',Program Pascasarjana

Universitas Sebelas Maret. Surakarta.

TIM FIP, 2009.'Pedoman Penilaian Kinerja

Dosen'. Fakultas Ilmu Pendidikan Universitas Indonesia. Depok.

Tim Puslasdikkes, 2014. 'Pedoman Penghitungan Beban Kerja Dosen, Badan Pengembangan dan Pemberdayaan SDM Kesehatan Pusat Pendidikan dan Pelatihan Tenaga Kesehatan', Kementrian Kesehatan RI. Jakarta 